\title{
NITROGEN FELTILIZER RESPONSES ON HILI. COUNTRY PASTURES
}

\author{
P. C. Luscombe
}

\section{Grasslands Division, DSIR, Palmerston North}

\begin{abstract}
The response of hill pastures to $\mathrm{N}$ fertilizer was measured at Ballantrae, the Grasslands Division, DSIR, hill country research station. Both initial and residual responses were affected by the timing and rate of nitrogen fertilizer applications. The pasture response at lower rates of $\mathrm{N}$ varied between 10 and $25 \mathrm{~kg} \mathrm{DM} / \mathrm{kg} \mathrm{N}$, while at higher rates the efficiency of $\mathrm{N}$ use was reduced to 5 to $7 \mathrm{~kg} \mathrm{DM} / \mathrm{kg} \mathrm{N}$.

Most efficient use of nitrogen occurred on cool aspects. An analysis of the profitability of using fertilizer $\mathrm{N}$ to intensify hill country sheep farming suggests that fertilizer $\mathrm{N}$ may be useful where additional animals can be carried, by providing nitrogen-boosted pasture for a limited period over the winter/spring months.
\end{abstract}

\section{INTRODUCTION}

FIELD AND BALL (1978) suggest that fertilizer $\mathrm{N}$ used as a tactical input to increase seasonal pasture productivity has its greatest relevance in farming situations where output is limited by consistent and predictable feed shortages.

Ball et al. (1976) obtained $a$ large pasture response to fertilizer $\mathrm{N}$ on southern Hawke's Bay hill country when a tactical application was used to offset a predicted seasonal feed shortage on a heavily stocked farm.

Sherlock and O'Connor (1973) reported large $\mathrm{N}$ responses from mown trials at Te Kuiti which would, on the costs and prices of 1972, support the use of fertilizer $\mathrm{N}$ in beef breeding operations to avoid winter-early spring under-feeding of cows. Carrying extra store cattle through the winter and selling on the rising spring market, as opposed to selling on the autumn market, is advocated by Nielson (1974) as a likely profitable alternative cattle policy.

Seasonal N deficiency in southern Hawke's Bay hill country pastures was assessed in 1977-9, and results for trials investigating $\mathrm{N}$ response in autumn, winter and spring are presented in this paper.

\section{EXPERIMENTAL}

The study was conducted at Ballantrae, the hill country research station of Grasslands Division, DSIR, in the southern Ruahine Range, near Woodville. 

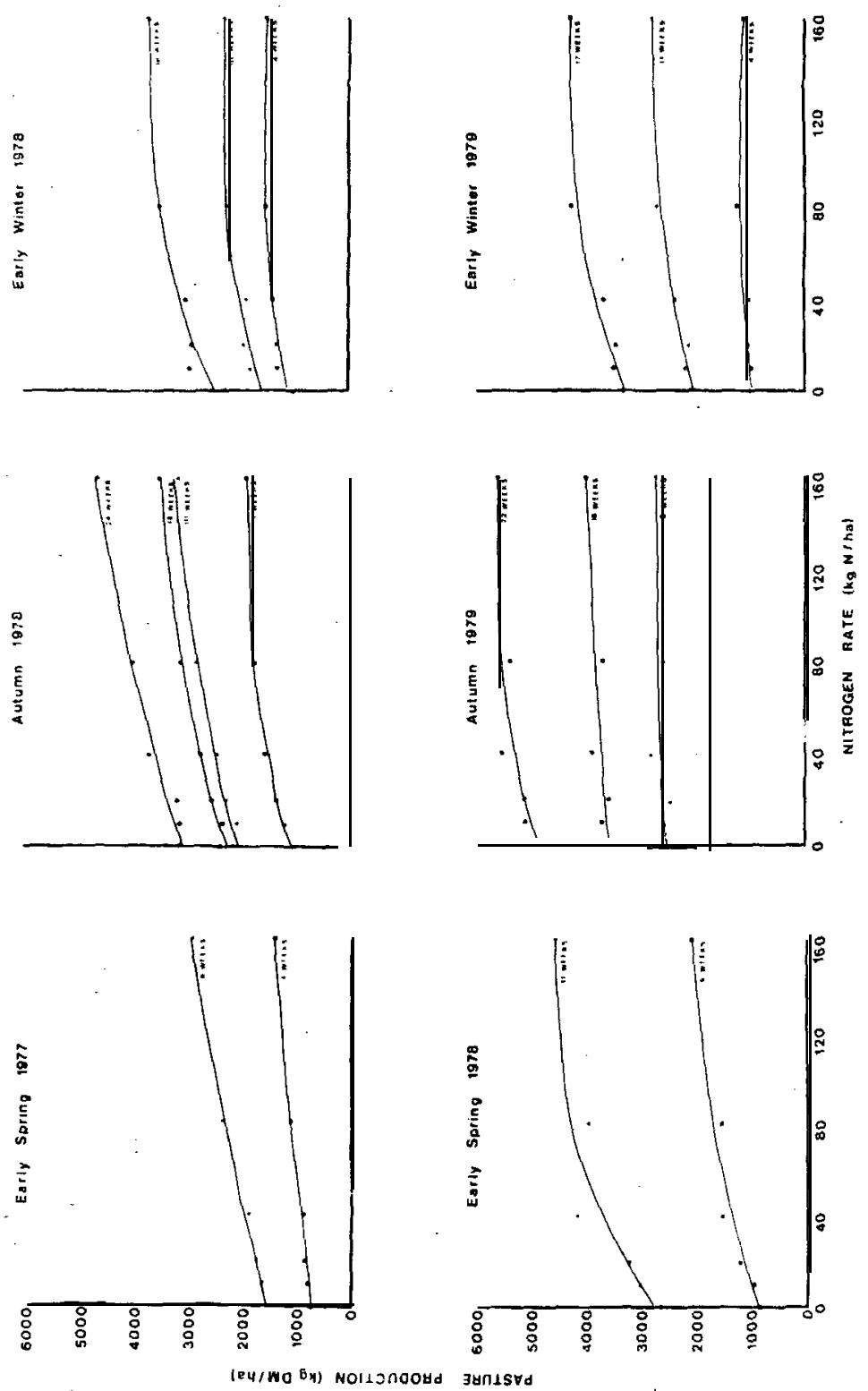

FIG. 1: Cumulative pasture production at each harvest time over the nitro gen response period of each seasonal trial. 
An area on Taihape steepland soil formed from sandy siltstone under a rainfall of approximately $1100 \mathrm{~mm}$ was used for the trial. Although it had no known fertilizer input prior to 1973, phosphate fertilizer inputs have subsequently been high (a total of $1875 \mathrm{~kg} / \mathrm{ha}$ superphosphate between 1973 and 1976). Lime (1250 kg/ha) and $20 \mathrm{~kg}$ nitrogen/ha were applied in 1975. Soil quicktest values in 1976 were 8 and 7 for Olsen P and exchangeable $\mathrm{K}$, respectively. Total soil carbon and nitrogen were 5.17 and $0.355 \%$, respectively, giving a $\mathrm{C}: \mathrm{N}$ ratio of 14.6 . The $\mathrm{pH}$ was 5.4 .

Six sites were selected on areas of uniform pasture with a 10 to 15 " slope. There were three on a warm north-easterly aspect and three on a cool south-westerly aspect. At each site small-plot trials were established for each application date. Plots were $0.5 \mathrm{~m}^{2}$, with $0,10,20,40,80$ or $160 \mathrm{~kg} \mathrm{~N} / \mathrm{ha}$ applied as urea on 13 September 1977; 4 April, 16 May, 16 August 1978; and 9 April and 14 May 1979. A new area was selected for each application date. Superphosphate $(750 \mathrm{~kg} / \mathrm{ha})$ and muriate of potash $(200$ $\mathrm{kg} / \mathrm{ha}$ ) were applied 3 weeks prior to $\mathrm{N}$ application to avoid possible $\mathrm{P}, \mathrm{K}$ or $\mathrm{S}$ limitations. Pasture dry matter (DM) production and composition were assessed. Each trial was cut at approximately monthly intervals for the duration of the $\mathrm{N}$ response period, although the period between cuts was longer over the winter period when growth was slow.

\section{RESULTS AND DISCUSSION}

\section{YIELD RESPONSES}

Pasture yield data are presented in Fig. 1. These are means of six sites.

Figure 2 shows the pasture response per unit of fertilizer nitrogen applied for the six trials and demonstrates the declining efficiency of $\mathrm{N}$ use with increasing application rates.

Although the 1978 autumn trial showed a large initial response, the 1979 autumn trial showed little initial response (Fig. 1). The residual effects were considerably greater in the 1979 trial, giving a similar total response in both trials. The seasonal difference is likely to be attributable to the summer/early autumn weather which was considerably drier in the 1978 season.

In contrast, in both seasons the late autumn/early winter $\mathrm{N}$ application trials had small initial responses, with large residual responses over the winter/spring period. These results emphasize the importance of assessing fertilizer $\mathrm{N}$ responses over a longer period than an initial 4- to 6-week growth period. 

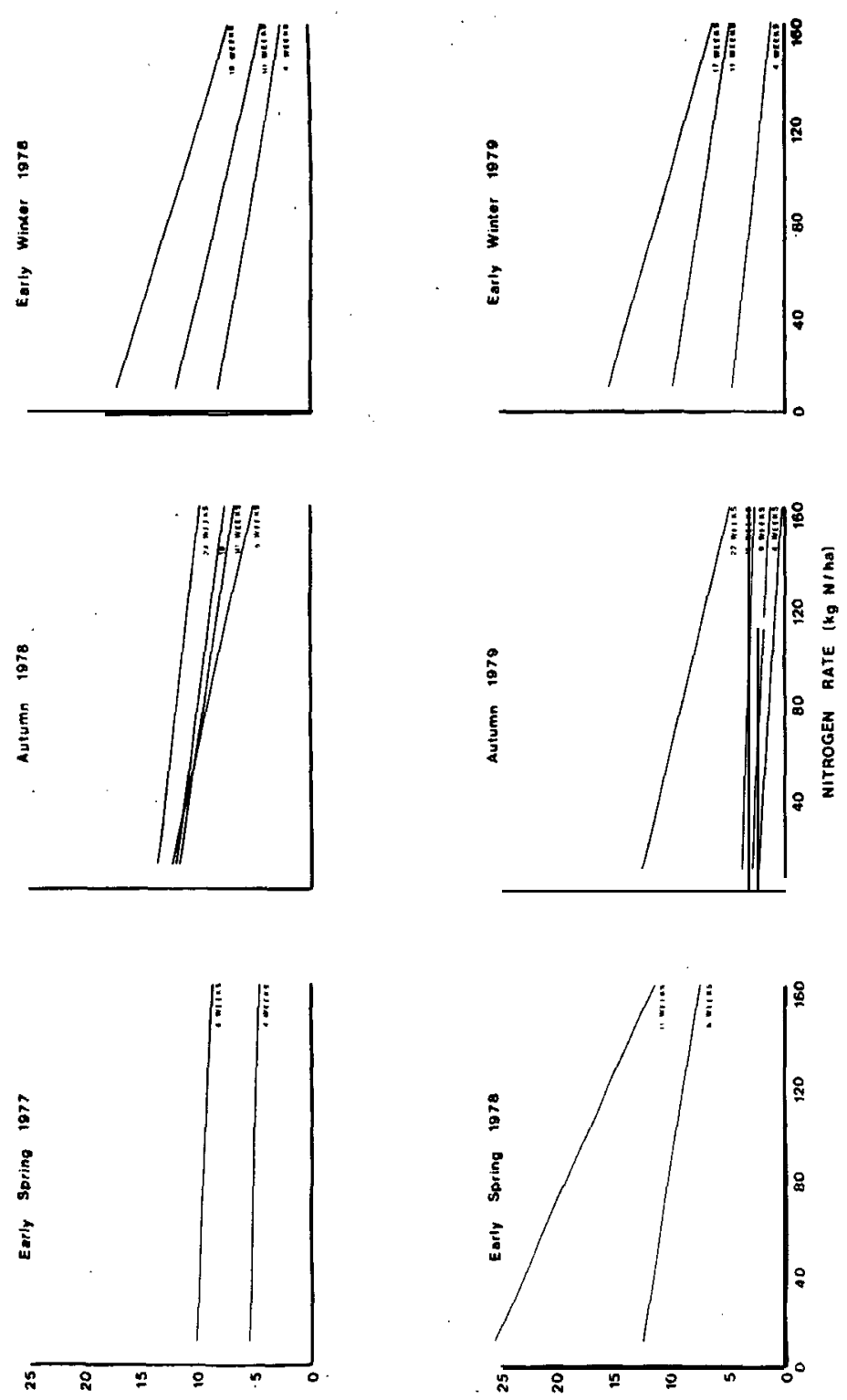

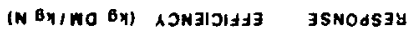

FIG. 2: Total pasture response per unit of fertilizer nitrogen, at each harvest time of the seasonal trials. 
The response from an August $\mathrm{N}$ application was markedly larger than that obtained from the mid-September application. This is consistent with the results of lowland trials (Field and Ball, 1978). Residual responses were again large in relation to initial response. The similar efficiency of use of $\mathrm{N}$ fertilizer at high and low rates in the later spring trial may reflect the greater potential for grass growth in spring.

These large $\mathrm{N}$ responses, with a large proportion of the response occurring after 3 to 4 weeks, are consistent with the results obtained by Sherlock and O'Connor (1973) in Te Kuiti hill country and Ball et al. (1976) in southern Hawke's Bay hill country. Sherlock and O'Connor concluded that total $\mathrm{N}$ response was largely unaffected by timing of $\mathrm{N}$ application over the April to September period, as in cooler winter months where initial response was smaller, larger residual responses were obtained. Although the responses shown here (Figs. 1 and 2) support this trend, it is important to note that the largest total responses occurred in the late winter/early spring trial, where the largest initial response was also measured. A substantially lower $\mathrm{N}$ response from September application compared with August application was also evident in the trials of Sherlock and O'Connor (1973) .

It should be recognized that these nitrogen efficiencies were obtained under cutting, and that higher efficiencies could be expected under grazing (Brockman, 1969; Brockman et al., 1971).

\section{EFFECT OF ASPECT}

Aspect had a distinct effect on yield over the spring period.

The data suggest that the cool aspect slopes may give a more efficient response to $\mathrm{N}$ than will the warm slopes.

\section{SPECIES YIELDS}

Figure 4 shows yields of ryegrass, other grasses and clovers, and demonstrates the major contribution of other grasses in the nitrogen response, supporting the conclusion of Ball et al. (1976) that many "low fertility-tolerant" species have considerable potential for increased production given nitrogen fertilizer. The other grass species making major contributions were browntop (Agrostis tenuis Sibth.), crested dogstail (Cynosurus cristatus L.) and sweet vernal (A nthoxanthum odoratum L.). Ryegrass showed 


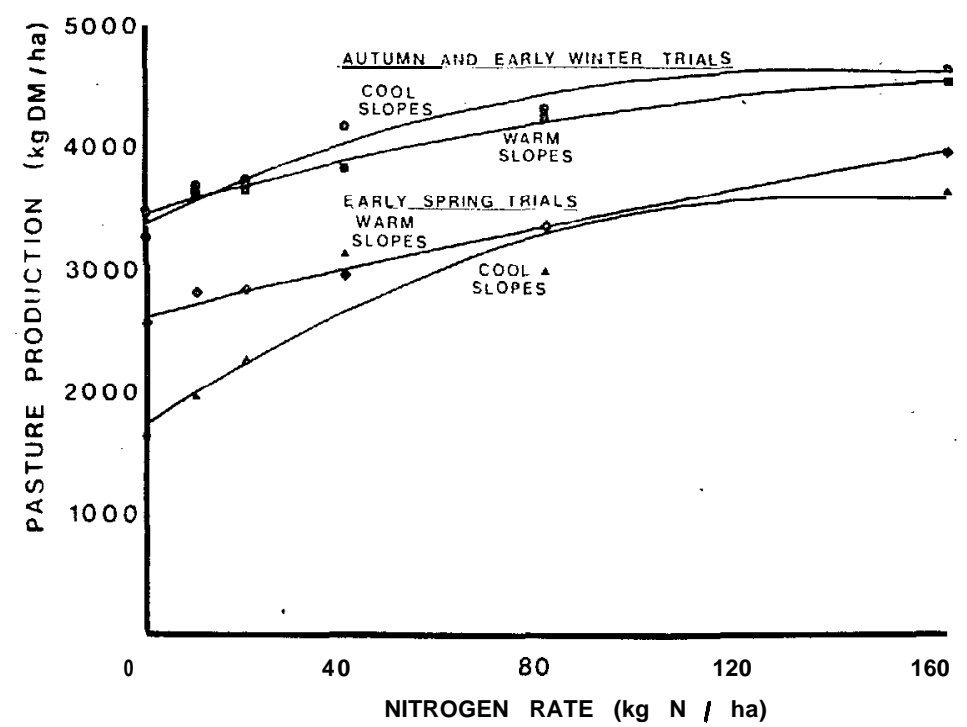

FIG. 3: Mean nitrogen response on cool aspect slopes and on warm aspect slopes from autumn and early winter trials, and from early spring trials.

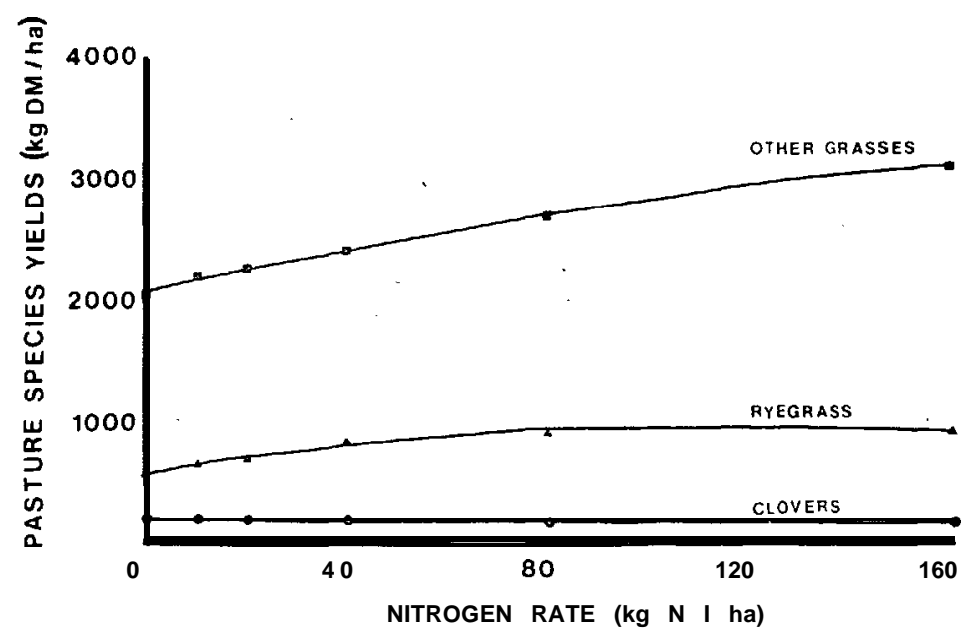

FIG. 4: Mean pasture species yields of ryegrass, other grasses, and clovers, at each rate of fertilizer nitrogen. 
no increase in contribution to the sward following $\mathrm{N}$ fertilizer application as has been suggested may occur (Nielson, 1973). Clover yields (mainly Trifolium repens $\mathrm{L}_{\text {.) }}$ were little affected by $\mathrm{N}$ fertilizer.

\section{ECONOMIC ANALYSIS}

Annual patterns of pasture growth and seasonal feed requirements of breeding ewes (summarized for a range of N.Z. districts by Rattray, 1978) indicate that pasture growth over the winter/ spring period often limits stock carrying capacity. As a result, surplus feed, which often cannot be harvested on hill country, accumulates later in spring and leads to pasture of very low digestibility over the following summer and autumn (Rattray, 1978) and penalizes the sward legume component. Overcoming the winter/early spring feed deficit may allow intensification.

The likely profitability of using $\mathrm{N}$ fertilizer to intensify these pastoral systems can be assessed by comparing the cost of providing additional pasture with the return from the extra animal production. The size of the $\mathrm{N}$ input required to meet a predicted feed shortfall calculated from breeding ewe requirements (Rattray, 1978) is given for three periods in Table 1. While the results from this study (Fig. 2) suggest that a response efficiency of $15 \mathrm{~kg}$ $\mathrm{DM} / \mathrm{kg} \mathrm{N}$ from $\mathrm{N}$ applications up to 40 to $80 \mathrm{~kg} \mathrm{~N} / \mathrm{ha}$ may be a feasible basis on which to base calculations, animal grazed trials may give a greater response and so reduce nitrogen requirements.

Feed costs per ewe are $\$ 30, \$ 15$ and $\$ 8$, respectively, for the three periods shown in Table 1 if a response of $15 \mathrm{~kg} \mathrm{DM} / \mathrm{kg}$

TABLE 1: NITROGEN FERTILJZER REQUIRED ( $\mathrm{kg} \mathrm{N}$ ) TO GROW SUFFICIENT PASTURE FOR A BREEDING EWE* (ASSUMING AN 80\% UTILIZATION OF FEED GROWN) OVER THREE PERIODS, AT A RANGE OF PASTURE RESPONSE EFFICIENCIES.

\begin{tabular}{|c|c|c|c|c|}
\hline \multirow{2}{*}{$\begin{array}{c}\text { Pasture Response } \\
\text { per } \mathrm{kg} \text { of } N \\
(\mathrm{~kg} D M / \mathrm{kg} \mathrm{N})\end{array}$} & \multirow[b]{2}{*}{ Year } & \multicolumn{3}{|c|}{$\mathrm{N}$ Fertilizer Rate $(\mathrm{kg} N)$} \\
\hline & & $\begin{array}{l}\text { Four Months } \\
\text { (winter/early spring) }\end{array}$ & $\begin{array}{l}\text { Two M onths } \\
\text { (late winter/early }\end{array}$ & spring) \\
\hline 30 & 20 & 10 & 5 & \\
\hline 20 & 30 & 15 & 8 & \\
\hline 15 & 40 & 20 & 10 & \\
\hline 10 & 60 & 30 & 15 & \\
\hline 5 & 120 & 60 & 30 & \\
\hline
\end{tabular}

*From Rattray (1978): Year requirement: $600 \mathrm{~kg}$ DM: four months' requirement: $300 \mathrm{~kg} \mathrm{DM}$; two months' requirement: $150 \mathrm{~kg} \mathrm{DM}$. 
$\mathrm{N}$. is assumed at the current cost of 75 cents $/ \mathrm{kg} \mathrm{N}$ applied. Replacement stock would involve extra expenditure. The gross margin of \$20/ewe in 1978-9 (MAF Gross Margins Publication, 1979) suggests that nitrogen use on this hill country may be a profitable venture where additional feed is required only over a 2- to 4-month period in winter and early spring. However, there are long-term benefits from the ability to winter more stock and the consequent better utilization of spring pasture is likely to improve subsequent summer and autumn feed quality. This will also further contribute to the profitability of $\mathrm{N}$ use in hill country systems.

In conclusion, it is emphasized that these calculations will require reworking for each district and farming situation where the additional feed requirements, the nitrogen response and nitrogen cost will vary. These trials emphasize that more information is required on $\mathrm{N}$ fertilizer responses in hill country. It appears that hill country sheep farms may offer a system where efficient use could be made of fertilizer nitrogen, allowing profitable intensification with minimal additional capital or labour inputs.

\section{ACKNOWLEDGEMENTS}

D. A. Grant, Roger Ball and M. G. Lambert, Grasslands Division, DSIR, Palmerston North, for their help in planning this study; D. A. Clark for assistance in the preparation of this paper; Miss Yvonne Gray and the staff of the Herbage Laboratory for herbage dissections.

\section{REFERENCES}

Ball, R.; Inglis, I. A. H.; Mauger, J. H., 1976. Proc. N.Z. Grassld Ass., 37: $72-81$.

Brockman, J. S., 1969. J. Ir. Grassld Anim. Prod. Ass., 4: 13-9.

Brockman, J. S.; Rope, C. M.; Stevens, M. T., 1971. J. Br. Grassld Soc., 26: 209-12.

Field, T. R. 0.; Ball, R., 1978. Proc. A gronomy Soc, N.Z., 8: 129-33.

MAF Gross Margins Publication, 1978-9. Advisory Services Division, MAF, Palmerston North.

Nielson, B. A., 1973. N.Z. Fert. J., 42: 10-1.

1974. Ibid., 43: 11-2.

Rattray, P. V., 1978. Proc. Agronomy Soc. N.Z., s: 103-S,

Sherlock, R. R.; O'Connor, M. B., 1973. Proc. N.Z. Grassld Ass., 35: 52-62. 